\title{
Brazilian science searches for new direction
}

São Paulo. Three separate studies of the state of science and technology in Brazil have provoked soul searching among the country's scientists. The studies all call for increased financing of applied research, and for increased links with private enterprise.

But doubts still linger about the wisdom of dumping a model based on state-sponsored basic research that has achieved good results in the recent past, even though it is recognized that this model may no longer be appropriate in a world characterized by lower trade barriers and increased pressure to achieve international competitiveness.

The studies were commissioned by the Ministry of Science and Technology at the request of international agencies such as the World Bank. Published in May, near the end of the current government's term (elections are in October), they set a framework for the science policies of its successor.

"We need to stop the decline in resources, stop the brain drain, make efforts to work with private enterprise, and stop big projects that have not worked, such as the nuclear energy deal with Germany," says Simon Schwartzman, a researcher at University of São Paulo and Getlio Vargas Foundation, who coordinated one of the studies.

There are already signs that the government acknowledges the dangers of cutting back support for research. In one of its last acts before the election, it has increased funding for the Ministry of Science and Technology by 6 per cent next year, at a time when almost all other ministries have exper- ienced cuts of between 16 and 20 per cent.

The largest of the three studies, costing US\$1.6 million and spawning a 6,000-page document, focused on the competitiveness of Brazilian Industry, and was coordinated by economist Luciano Coutinho, of the State University of Campinas (Unicamp) in São Paulo State.

The second study, coordinated by Schwartzman, dealt with the current status of several areas of science and technology in Brazil, notably in universities and research institutes. The third, dealing with the institutional framework for financing research, was compiled by Francisco Biato of the Ministry of Economy.

Speaking at a meeting organized by the Getlio Vargas Foundation - a

\section{Universities in bid to take over research institute}

London. A consortium of three universities this week unveiled plans to take over the Natural Resources Institute (NRI), a major government research institute, just a few months after the government's multi-departmental efficiency scrutiny recommended that transfer of research institutes to universities should be considered "routinely" (see Nature 370, 89; 1994).

Under the proposal, put to the Overseas Development Administration (ODA) earlier this month, the NRI's active research arm and the laboratories at Chatham, southern England, would be taken over by the University of Greenwich. The marketing and business side of the NRI would become a separate non-profit company jointly owned by the three colleges making up the consortium, the University of Greenwich, the University of Edinburgh and Wye College, part of the University of London.

The announcement comes as the University of Greenwich is in the process of moving its School of Earth Sciences to NRI's site in Chatham. The NRI had been seeking a sub-tenant since 1992 to rent excess office and laboratory space. The university and NRI will offer joint courses from September.

Other research institutes are watching this move, and any subsequent developments on the ownership of the NRI, with interest, in light of the recommendations by the scrutiny team, which are in a four-month consultation period until November.

Earlier this month the ODA, the current owners of NRI, announced Phase
II of a special ownership study to investigate further the options for ownership of NRI. Phase I of the study, commissioned by the ODA in January, included the possibility of the transfer of NRI to a university.

The NRI, which specializes in research in natural resource management in developing countries, including resource assessment and pest management, was formed in 1987 by the amalgamation of the Tropical Development and Research Institute and the Land Resources Development Centre. It was made an agency of the ODA in 1990 as part of the government's plans to prepare some public-sector research institutions for privatization.

Rob Black, who is chairman of the ODA branch of the Institution of Professionals, Managers and Specialists (IPMS), the main union of the $530 \mathrm{NRI}$ staff, said that union members had yet to be consulted on the plans put forward by the consortium, which were only made public this week. But he did expect that NRI staff would be asking the ODA for assurances that job losses would be kept to a minimum and that there would be some continuity in terms of the naming of the institute, which has undergone several changes in its recent history.

Staff are right to be sceptical, according to Valerie Ellis, assistant general secretary of the IPMS. Although the union is in favour of university links, there may be hidden dangers because universities are not as close to research institutes as may be imagined, she says.

"The major problem is that NRI's mission is about helping developing countries, including technology transfer, and that's why its a government laboratory and not a university department already," argues Ellis.

Despite claims by Sir Peter Levene, head of the efficiency scrutiny team, that rationalization does not necessarily mean job cuts, staff are concerned that phase II of the ownership study will mean more redundancies on top of the 47 already this year.

"I think everybody accepts that NRI will diminish in size, [but] I still think most people probably would prefer to remain in the civil service as an agency, that they do their job best in that way," says Black.

Lady Chalker, minis-

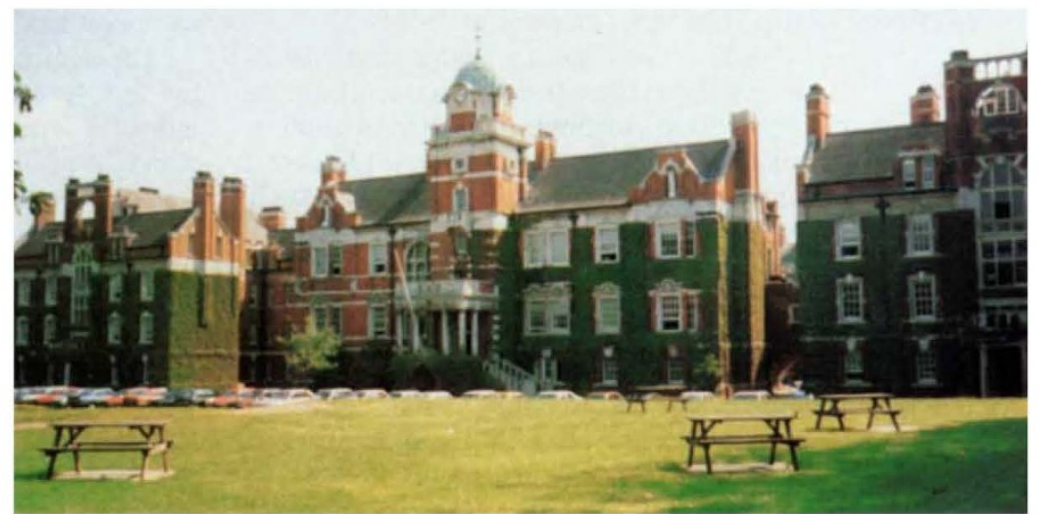

The University of Greenwich will share NRI's site at Chatham in Kent. ter for overseas development, will ultimately make the decision on ownership, probably by the end of this year. But NRI is quite sure of its preferred option. "I think there's no doubt at all that it's going to be quite difficult to find an ownership option which has as many of the attractions of merging with a university,"says Anthony Beattie, chief executive of NRI.

Maggie Verrall 
business and public administration school - in São Paulo, Michael Gibbons, director of the Science Policy Research Unit at the UK University of Sussex, summarized the situation by pointing out that "the scientific, technological and educational developments established in the 1970 s no longer seem to be working".

The three papers indicate that the main reason is economic. Most of the major institutions associated with the development of a robust national scientific and technological capability - in particular government research establishments and universities are in financial difficulty, and their links with industry remain weak.

There is a general consensus that the private sector should do more to support science. Only 15 per cent of the country's bill for research and development is paid by the private sector, compared to around 70 per cent in some Asian countries such as Taiwan, Korea and Japan.

Yet how to attain the competitiveness of the Asian 'tigers' remains hotly debated. Many at the Getlio Vargas meeting felt that this could still be achieved through State backing for basic science.

But others pointed out that India, for example, is a Third World country that has invested heavily in science with only limited results in terms of economic development; they suggested instead that Brazil copy the market-driven, low-to-high-tech approach of countries such as Taiwan and South Korea.

Whichever path is taken, one hurdle remains: the antiquated Brazilian state. Any science and technology policy requires a stable economy, if it is to be successful, and in the case of Brazil this may need long-term reform of the state.

Brazil still lacks a unified science policy. Ivan Rocha, of the University of Brasilia, who participated in Biato's study, says that science funding agencies need to link science to broader industrial and educational goals; otherwise funding agencies will continue "shooting in all directions", he says.

The next government will have to deal with the big projects of the past, including schemes for a nuclear submarine, military aircraft and a space rocket launcher. Military research still accounts for one-fifth of the government's spending on research.

Some are demanding reductions in such spending. But others, such as Geraldo Lesbat Cavagnari Filho, a former Army colonel, who is now a researcher at Unicamp, says the government should finish what has already been started.

Cavagnari has given this advice to the presidential candidate now second in public opinion pools, Luiz Incio Lula da Silva, of the left-wing Workers Party (Partido dos Trabalhadores). Many scientists may not like it. But, as Cavagnari says, they have much to lose, as 90 per cent of the armed forces' researchers are civilians.

Ricardo Bonalume Neto

\section{Koop may set up new centre for alternative medicine}

Washington. Joseph Jacobs, who steps down in October as head of the Office of Alternative Medicine at the US National Institutes of Health (NIH), may be about to join forces with C. Everett Koop, the outspoken surgeon general in the Reagan administration, in setting up a centre for alternative medicine at Dartmouth Medical College in New Hampshire.

The Koop Institute at the college promotes curriculum changes in medical schools. David Serra, a co-director of the institute, confirmed rumours that Koop was having discussions with Jacobs but refused to say about what. He did say that if such a centre went ahead its aim would be to investigate alternative therapies with the assumption that some regimens work. But, he added, "we can't get too far ahead of ourselves because there is some opposition within Dartmouth".

Jacobs and Koop both believe that primary care could play a greater role in health care in the United States (see Nature 370, 501 ; 1994). Jacobs, who is reticent about his future plans, says that it is in this context that he would like to see alternative medicine given more serious attention.

Jacobs has had a rough ride as the first head of the Office of Alternative Medicine, which was established by a congressional mandate to further research into practices such as acupuncture and herbalism. Colleagues say that he has been caught between the traditional biomedical community and extremists in alternative medicine.

"My critics at both ends of the spectrum are caught in a mind set of 20 years ago," says Jacobs. "A way forward for alternative medicine is through primary health care. The critics and zealots don't really understand that. They are in a political battle and are using the NIH as a battlefield," he added.

Jacobs believes that the Office of Alternative Medicine should not be attached to the National Institutes of Health, which he says is a "highly specialized, quintessential research organization" that is not suited to the more mundane research needed in alternative medicine. Nevertheless, he believes that to dismiss conventional medicine is narrow-minded. Like many at the centre of the debate, Jacobs would be more comfortable if alternative medicine were called complementary medicine (as it is in much of Europe).

Steve Martin, assistant professor of medicine and of the history and philosophy of medicine at the Albert Einstein

College of Medicine in New York, says, "the term alternative medicine encompasses a wide array of techniques, some compatible with conventional medicine, some not".

If Koop and Jacobs do establish a centre for alternative and complementary medicine at Dartmouth, they will join a small group of respected medical schools, such as Harvard and Columbia, that have set up

IMAGE UNAVAILABLE FOR COPYRIGHT REASONS

\section{Acupuncture gains credibility as an alternative therapy.}

similar centres within the past year or so.

In fact, a paper published in the New England Journal of Medicine last year by David Eisenberg, who established Harvard's centre, has provided some of the impetus behind the increasing interest of medical students and faculty in alternative practices. Eisenberg concluded from a telephone survey that, in 1990, Americans spent about US\$13.7 billion on alternative therapies.

One of the most widely used of these alternative therapies was acupuncture. The Office of Alternative Medicine has collected data from clinical trials that lawyers representing acupuncturists were to present this week as part of a petition to have acupuncture needles removed from the Food and Drug Administration's (FDA)'s list of investigational devices.

Investigational devices should be used only experimentally, but, in practice, acupuncture needles are widely used for treatment. James Turner, the lawyer presenting the petition, expects a decision from the FDA within the next six months. If acupuncture needles are taken from the list of investigational needles, it will be possible for patients to reclaim the cost of treatment from federal programmes that pay for the health care of the elderly and the poor.

The next item on the agenda of the Office of Alternative Medicine is to persuade the FDA to allow some clinical trials of Chinese herbs. One application was submitted by Freddie Kronenberg, a physiologist who heads Columbia's centre for alternative and complementary medicine. She wants to investigate the effectiveness of Chinese herbs for the relief of hot flushes during the menopause.

Helen Gavaghan 